\title{
Peculiarities of the molecular composition of heterochromatin associated with pronucleoli in mouse embryos
}

\author{
I.O. Bogolyubova ${ }^{1} \otimes$, Z.K. Sailau ${ }^{2}$, D.S. Bogolyubov ${ }^{1}$ \\ ${ }^{1}$ Institute of Cytology, RAS, St. Petersburg, Russia \\ ${ }^{2}$ St. Petersburg State University, Russia \\ هe-mail: ibogol@mail.ru
}

\begin{abstract}
The nucleus of pre-implantation mammalian embryos is characterized by peculiar structural organization. At the initial stages of cleavage, the nucleus of the embryo contains the so-called nucleolus precursor bodies (NPBs) or pronucleoli rather than functionally active nucleoli. The NPBs are fibrillar electron-dense structures inactive in RNA synthesis. The vast majority of NPBs are surrounded by a ring-shaped zone of transcriptionally inactive heterochromatin. Intriguingly, these zones contain not only tri-methylated histone H3K9me3 as an epigenetic mark of repressed chromatin but also acetylated histone H4K5ac, a well-known marker of active chromatin. Immunocytochemical data suggest that the molecular composition of this'ring heterochromatin' in mouse embryos changes during the realization of embryonic genome activation events, as well as during artificial suppression of transcription. In zygotes, some factors of mRNA biogenesis including splicing factor SC35 (SRSF2) and basal transcription factor TFIID are detectable in the ring chromatin. At later stages of development, other nuclear proteins such as $Y 14$, a core component of the exon-exon junction complex (EJC), as well as the proteins involved in chromatin remodeling (ATRX, Daxx) are also detectable in this area. A typical component of the 'ring heterochromatin' is actin. Anti-actin immunocytochemical labeling is most expressed at the two-cell cleavage stage after activation of the embryonic genome. Indicatively, the molecular composition of the 'ring heterochromatin' associated with different NPBs may differ significantly even in the same nucleus. This seems to reflect the functional heterogeneity of morphologically similar NPBs according to their competence to the process of nucleologenesis. Here, we discuss briefly some peculiarities of the molecular composition and possible functions of the NPB-associated heterochromatin in mouse early embryos.
\end{abstract}

Key words: heterochromatin; pre-implantation mouse embryos; immunocytochemistry.

For citation: Bogolyubova I.O., Sailau Z.K., Bogolyubov D.S. Peculiarities of the molecular composition of heterochromatin associated with pronucleoli in mouse embryos. Vavilovskii Zhurnal Genetiki i Selektsii=Vavilov Journal of Genetics and Breeding. 2019;23(2):129-134. DOI 10.18699/VJ19.471

\section{Особенности молекулярного состава гетерохроматина, ассоциированного с проядрышками в эмбрионах мыши}

\author{
И.О. Боголюбова ${ }^{1} \otimes$, Ж.К. Сайлау르, А.С. Боголюбов ${ }^{1}$ \\ 1 Институт цитологии Российской академии наук, Санкт-Петербург, Россия \\ ${ }^{2}$ Санкт-Петербургский государственный университет, Санкт-Петербург, Россия \\ 凶e-mail: ibogol@mail.ru
}

Ядро доимплантационных эмбрионов млекопитающих характеризуется своеобразной структурной организацией. На начальных стадиях дробления вместо функционально активных ядрышек в ядре эмбриона присутствуют так называемые проядрышки - фибриллярные электронно-плотные структуры, неактивные в отношении синтеза РНК. Подавляющее большинство проядрышек окружено кольцеообразной зоной транскрипционно неактивного гетерохроматина, который, однако, содержит не только эпигенетическую метку репрессированного хроматина - триметилированный гистон Н3К9mе3, но и метку активного хроматина - ацетилированный гистон Н4К5ас. По результатам непрямого иммуномечения, молекулярный состав кольцевого гетерохроматина в эмбрионах мыши изменяется в ходе реализации процессов активации эмбрионального генома, а также при искусственном подавлении транскрипционной активности. На стадии зиготы в составе кольцевого гетерохроматина выявляются некоторые факторы метаболизма мРНК, например SR-белок фактор сплайсинга SC35 (SRSF2) и базальный фактор транскрипции TFIID. На более поздних стадиях развития в этой области начинают выявляться другие ядерные белки, например Ү14 - коровый компонент комплекса связи экзонов (EJC), а также белки, вовлеченные в ремоделинг хроматина - ATRX и Daxx. Типичным компонентом кольцевого гетерохроматина является актин, иммуноцитохимическое мечение которого наиболее выражено на двухклеточной стадии дробления, после активации эмбрионального генома. Характерно, что молекулярный состав гетерохроматина, ассоциированного с разными проядрыш- 


\begin{abstract}
ками в одном ядре, может различаться, что, возможно, отражает функциональную гетерогенность морфологически сходных проядрышек по их компетентности к процессу нуклеологенеза. В настоящем обзоре кратко обсуждаются некоторые особенности молекулярного состава гетерохроматина, ассоциированного c NPBs, и его возможные функции.

Ключевые слова: гетерохроматин; доимплантационные эмбрионы мыши; иммуноцитохимия.
\end{abstract}

\section{Introduction}

The combination of maternal and paternal gametes upon fertilization forms a totipotent embryo that will give rise to over 200 different cell types in a fully differentiated organism. The cardinal changes in the potency of cells to differentiate, as well as the integration of the parental genomes, are accompanied by pronounced rearrangements of the $3 \mathrm{D}$-organization of the nucleus in zygotes and early embryos. Correspondingly, the structure and organization of chromatin regions during early embryonic development differs fundamentally compared to somatic cells, reflecting the peculiar plasticity and potency of the genomes (Burton, Torres-Padilla, 2010). Global rearrangements of chromatin and major specific changes in DNA methylation, histone modifications as well as the incorporation of histone variants (Li, 2002; reviewed in Burton, Torres-Padilla, 2010; Mason et al., 2012) are the crucial reprogramming processes during the early steps of mammalian pre-implantation development (Lanctôt et al., 2007). In this review, some aspects of heterochromatin organization during the beginning stages of mouse development are briefly discussed.

\section{Nucleolus precursor bodies and surrounding heterochromatin are the unique nuclear structures of mammalian early embryos}

The unique feature of the nucleus of early mammalian embryos is the absence of functionally active nucleoli at the initial stages of embryonic development. Instead, the nucleus contains prominent electron-dense structures of perfectly round shape, called the nucleolus precursor bodies (NPBs) or pronucleoli (Fig. 1). A number of early autoradiographical studies (Geuskens, Alexandre, 1984; Tesařík et al., 1986a, b; Kopecný et al., 1989; etc.) has shown that NPBs are functionally linked with transcriptionally active nucleoli that are gradually formed later at species-specific embryonic stages. Unlike typical nucleoli of somatic cells, the pronucleoli (NPBs) of embryos consist only of a finely fibrillar and densely packed material of still unknown nature and do not contain typical nucleolar structural constituents such as dense fibrillar and granular components.

The vast majority of NPBs are surrounded by a characteristic ring-like zone of heterochromatin that is stained intensely with DAPI (see Fig. 1, $a^{\prime}, b^{\prime}$ ). Significantly, these peculiar zones are enriched in centromeric and pericentric satellite DNA in male and female pronuclei of zygotes. Later, this centromeric and pericentric heterochromatin re-localizes from the NPB periphery to the nucleoplasm at the two-cell stage, forming new structures called the 'pro-chromocenters' (Martin et al., 2006; Probst et al., 2007). The pericentric heterochromatin is enriched in HP1 (Heterochromatin Protein-1), and the HP1 $\beta$ isoform is prevalent in the NPB-surrounding heterochromatin in both male and female pronuclei of zygotes. HP1 $\beta$ is constitutively found in these heterochromatin areas until the blastocyst stage (Meglicki et al., 2012). In the mouse embryo, NPB-associated heterochromatin formation was found to require the histone variant $\mathrm{H} 3.3$, in particular di- and tri-methylation of lysine 27 residues (Santenard et al., 2010).
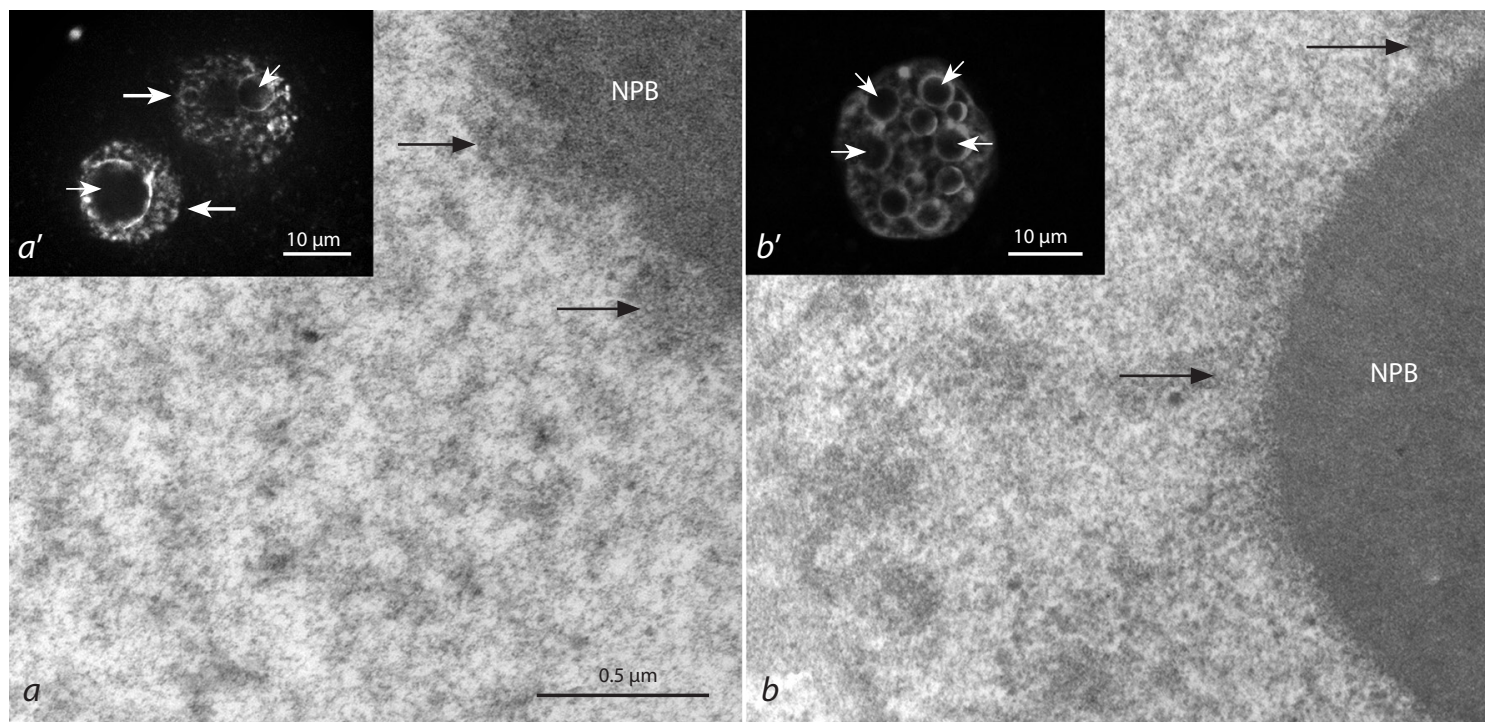

Fig. 1. Morphology of mouse zygotic pronuclei $(a)$ and two-cell embryo nucleus $(b)$.

$a, b$ - electron microscopy; $a^{\prime}, b^{\prime}$ - DAPI staining; NPB - pronucleolus. Large white arrows in $a^{\prime}$ indicate male (on the right) and female (on the left) pronuclei; small white arrows in $a^{\prime}$ and $b^{\prime}$ indicate some NPBs. Black arrows in $a$ and $b$ show heterochromatin clumps at the periphery of NPBs.

$a, b$ - from (Bogolyubova, Bogolyubov, 2013), open access; $a^{\prime}, b^{\prime}$ - from (Sailau et al., 2017), with permission from Elsevier. 
H3.3 is associated with paternal pericentric heterochromatin during the first S-phase and plays a role in the transcription of pericentric repeats and subsequent tethering of HP1 $\beta$.

\section{NPB-surrounding heterochromatin areas contains the epigenetic marks of both transcriptionally repressed and active chromatin}

The NPB-associated ring-like heterochromatin structures do not incorporate BrUTP (Fig. 2, a), suggesting their transcriptionally inert state (Bogolyubova, 2011; Bogolyubova, Bogolyubov, 2018). Surprisingly, these NPB-associated heterochromatin areas contain the markers of both repressed and active chromatin, e.g., the modified histones H3K9me3 and H4K5ac (see Fig. 2, $b, c$ ).

$\mathrm{H} 3 \mathrm{~K} 9 \mathrm{me} 3$ domains are linked with transcriptional regulation and intracellular functions in pre-implantation mouse embryos. These domains are formed temporarily after fertilization, then increase dramatically in the number at the two-cell stage and diminish after the morula stage (Wang et al., 2018). A comprehensive analysis of H3K9me3-dependent heterochromatin dynamics in pre-implantation mouse embryos has shown that this heterochromatin undergoes the dramatic reprogramming during early embryonic development. Intriguingly, H3K9me3 domains are highly enriched in long terminal repeats (LTRs) that are hypomethylated and transcribed (Wang et al., 2018). Besides, RNA sequencing throughout early mouse embryogenesis revealed that expression of the repetitive-elements including LINE-1 and IAP retrotransposons is dynamic and stage specific, with most repetitive elements becoming repressed before implantation (Fadloun et al., 2013).

\section{Molecular composition dynamics of NPB-surrounding heterochromatin}

The data obtain by indirect immunofluorescent microscopy (Table) suggest that the molecular composition of the NPB-
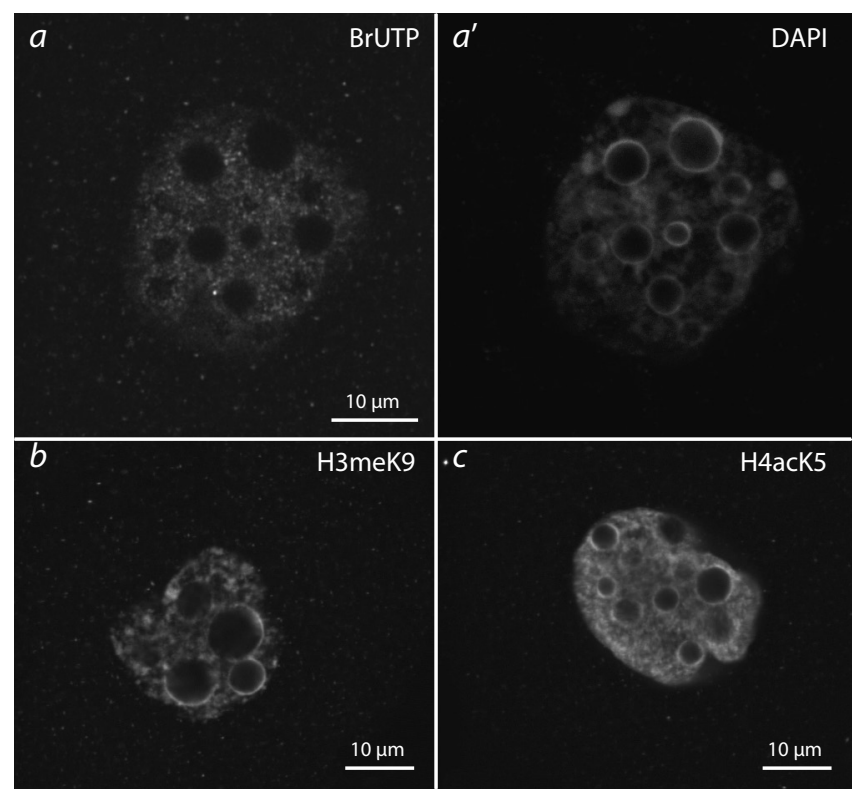

Fig. 2. Localization of BrUTP incorporation sites (a), H3K9me3 (b) and $\mathrm{H} 4 \mathrm{~K} 5 \mathrm{ac}(c)$ in the nuclei of late two-cell mouse embryos.

Note: the ring-like chromatin surrounding NPBs does not incorporate BrUTP but contains both $\mathrm{H} 3 \mathrm{~K} 9 \mathrm{me} 3$ and $\mathrm{H} 4 \mathrm{~K} 5 \mathrm{ac}$. Original.

surrounding heterochromatin including some chromatinassociated proteins, changes significantly during realization of the major events of embryonic genome activation as well as after artificial suppression of transcription. For example, some factors involved in mRNA metabolism including the spicing factor SC35 and basal transcription factor TFIID are revealed in the NPB-associated chromatin at transcriptionally inert stages (Bogolyubova, Bogolyubov, 2013) (Fig. 3). At later stages, however, other nuclear proteins (e.g., Y14, a core component of the exon-exon junction complex (EJC), the

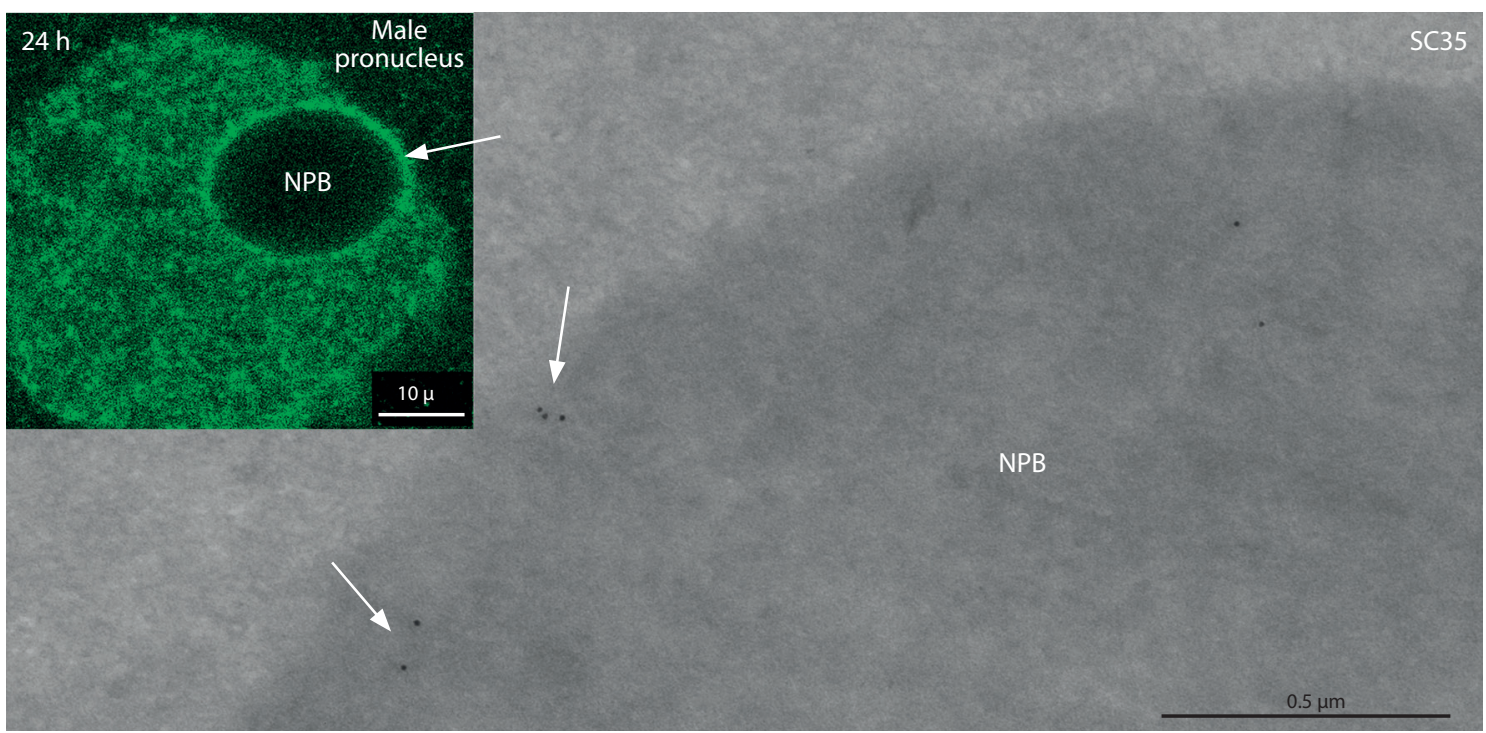

Fig. 3. Immunolocalization of the S/R-rich splicing factor SC35/SRSF2 in NPB-associated chromatin at an early stage (transcriptionally inert, $24 \mathrm{~h}$ post-hGG) of mouse development.

Arrows indicate anti-SC35 labeling in the vicinity of NPBs. Original; inset is from (Bogolyubova, Bogolyubov, 2013), open access. 
Immunocytochemical localization of some nuclear antigens in the NPB-associated heterochromatin in early mouse embryos

\begin{tabular}{|c|c|c|c|c|c|c|}
\hline \multirow[t]{2}{*}{ Protein studied } & \multicolumn{2}{|c|}{ Early zygote (20-24 h) } & \multicolumn{2}{|c|}{ Late zygote (27-28 h) } & \multirow{2}{*}{$\begin{array}{l}\text { Late two-cell } \\
\text { stage ( } 46-48 \text { h) }\end{array}$} & \multirow{2}{*}{$\begin{array}{l}\text { Artificial inhibition } \\
\text { of transcription }\end{array}$} \\
\hline & f & $\mathrm{m}$ & $f$ & $\mathrm{~m}$ & & \\
\hline H3K9me3 & ++ & $-/+$ & ++ & $-1+$ & $+/++$ & N/A \\
\hline $\mathrm{H} 4 \mathrm{~K} 5 \mathrm{ac}$ & - & + & - & + & $+/++$ & N/A \\
\hline Actin & - & + & - & + & ++ & $\uparrow$ \\
\hline SC35 splicing factor & + & + & - & - & - & - \\
\hline Basal transcription factor TFIID & + & + & - & - & - & - \\
\hline Chromatin-remodeling protein ATRX & - & - & + & + & ++ & + \\
\hline Daxx, a chaperone of the modified histone $\mathrm{H} 3 \mathrm{~K} 9 \mathrm{me} 3$ & + & + & ++ & ++ & ++ & $\mathrm{N} / \mathrm{A}$ \\
\hline Y14, an EJC core component & - & - & - & - & + & $\uparrow$ \\
\hline
\end{tabular}

Note: "-" - no labeling; "+" - weak labeling; "++" - strong labeling, " $\uparrow "-$ increased labeling intensity and/or the appearance of additional zones of labeling; $\mathrm{N} / \mathrm{A}$ - not available; $\mathrm{f}$ - female pronucleus; $\mathrm{m}$ - male pronucleus.
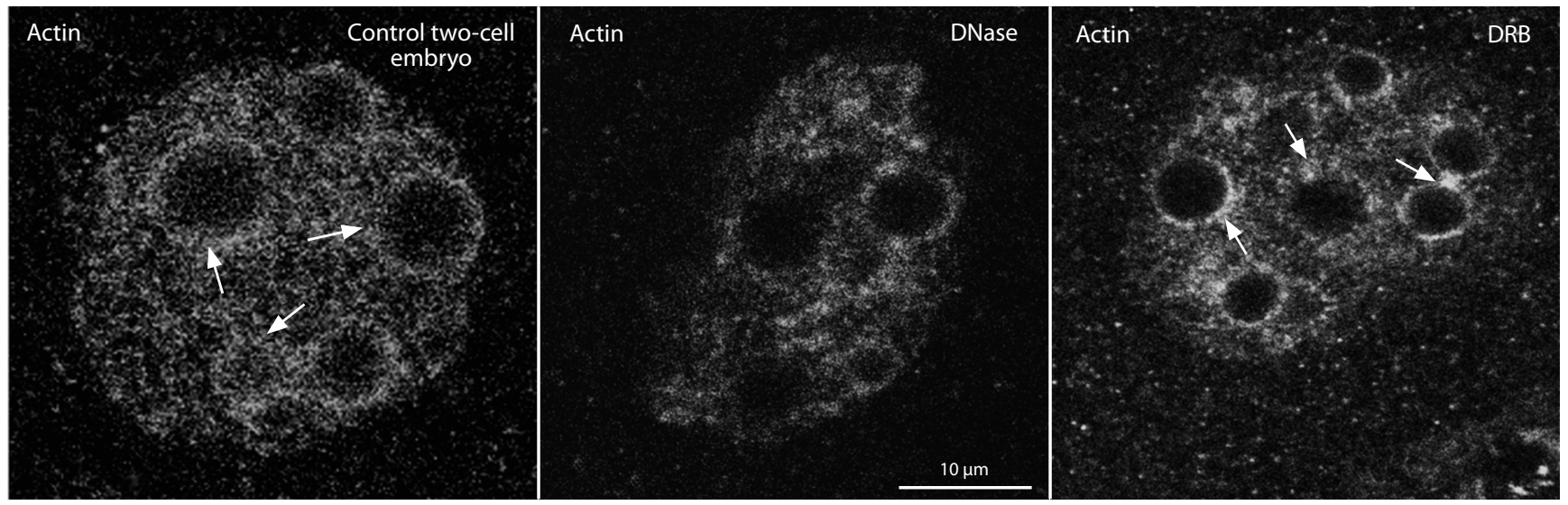

Fig. 4. Immunofluorescent localization of actin in the nuclei of two-cell mouse embryos.

Note: the prominent staining around NPBs (arrows), which becomes weaker after DNase treatment and enhances after inhibition of transcription by DRB. From (Bogolyubova, 2013), with permission from Tsitologiya.

chromatin-remodeling protein ATRX and Daxx, a chaperone of H3K9me3) begin to appear in the given area (see Table).

Also intriguing is the fact that the NPB-associated chromatin co-localizes with nuclear actin, and the anti-actin staining is most expressed at the transcriptionally active two-cell stage (Bogolyubova, Bogolyubova, 2009). When transcription was suppressed pharmacologically, actin continues to be revealed around the NPBs. Moreover, additional zones of its localization appear. The intensity of labeling decreases significantly after DNase treatment. This may suggest that actin is able to interact with DNA directly (Bogolyubova, 2013) (Fig. 4).

\section{Molecular composition of different \\ NPB-associated heterochromatin areas may differ one from another within the same nucleus}

This point is well illustrated by the peculiarities of the distribution of ATRX protein being detectable at the periphery of only several NPBs (Sailau et al., 2017) (Fig. 5). The peculiarities of the molecular composition of NBP-associated chromatin may reflect the functional heterogeneity of NPBs themselves. The change in the number of NPBs during embryo development, initially much higher than the number of active nucleoli that function at later stages of cleavage, allows us to believe that this heterogeneity is the reflection of the competence of individual NPBs to nucleologenesis.

The ideas concerning the heterogeneity of NPBs in relation to nucleologenesis were previously expressed by other authors. For example, L. Romanova et al. (2006) using the method of highly sensitive FISH, have shown that one or more NPBs are not associated with rDNA in the nucleus of early mouse embryos. In this regard, the authors speak about the heterogeneity of NPBs with the respect to their ability to bind rDNA and, therefore, about their different contributions to the formation of functionally mature nucleoli.

What stage of embryogenesis this heterogeneity is formed at? It is difficult to answer this question at the present time, since the molecular mechanisms of the assembly of NPBs remain virtually unexplored. There are only a few data concerning the molecular mechanisms of assembly and/or maintenance of the NPB structure. For example, both NPBs and NPB-associated heterochromatin were found to exhibit some abnormalities in the embryos of mice, knocked-out in the gene encoding the nucleolar transcription factor UBF (Hamdane et al., 2017). At the moment there are no data on 
differences in the morphology and/or molecular composition of the NPBs, associated and non-associated with rDNA. Therefore, it cannot be excluded that the formation of NPBs after fertilization and first division of cleavage occurs according to the mechanism of macromolecular crowding, and the local concentration of the constituent molecules plays a crucial role in this process. According to modern concepts, the macromolecular crowding is a general principle of the formation of nuclear organelles not surrounded by physical boundaries, such as the membranes (Richter et al., 2008; Rajendra et al., 2010; Cho, Kim, 2012). These nonmembrane organelles, also mentioned as the biomolecular condensates (Banani et al., 2017), are formed according to the laws of colloidal physical chemistry due to the concentration of the molecules in the process of liquid-liquid phase separation (LLPS) (Zhu, Brangwynne, 2015; Courchaine et al., 2016; Staněk, Fox, 2017; Gomes, Shorter, 2018; Sawyer et al., 2018a, b). It is possible that the association of individual NPBs with rDNA may be random at the initial stages of the formation of pronuclei.

From our point of view, despite the possible role of stochastic processes at the beginning steps of the formation of the NPB-heterochromatin complex, this complex can be regarded to as a multifunctional provisional domain of early embryos during embryonic genome activation, both components of which largely function as a whole. However, the mechanisms leading to the formation of this complex structure as well as the functional heterogeneity of NPBs require further studies, which have to combine classical morphological methods with modern molecular biological approaches.

\section{Conclusions}

Our observations generally show that the NPB-associated heterochromatin in one- to two-cell mouse embryos has a peculiar molecular composition, different from that of canonical peripheral heterochromatin. Since the nucleus of mammalian blastomeres represents a unique dynamic system at the early stages of cleavage (Bogolyubova, Bogolyubov, 2014), one can assume that in early embryos, a number of functional nuclear domains including the peculiar heterochromatin rims around NPBs have
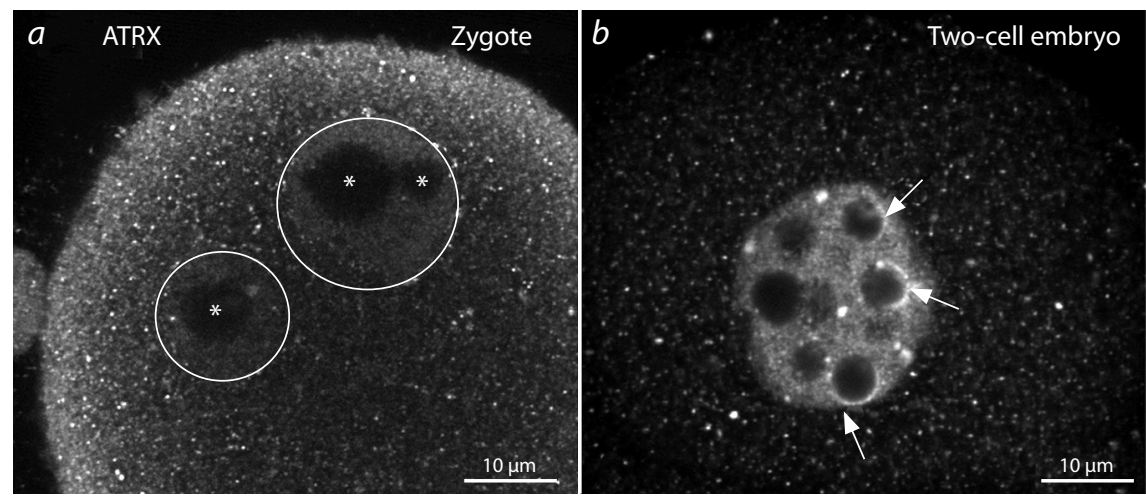

Fig. 5. Immunolocalization of the chromatin-remodeling protein ATRX in the nuclei of zygote $(a)$ and two-cell embryo (b).

$a$ - pronuclei are encircled, asterisks indicate NPBs. Note that ATRX is detectable in NPB-associated chromatin (arrows) only at the two-cell stage, and anti-ATRX staining is associated not with all NPBs. From (Sailau et al., 2017), with permission from Elsevier.

a wider range of functions than in somatic cells. For instance, a close relationship between the NPBs and NBP-associated heterochromatin with newly assembling Cajal bodies has already been shown (Ferreira, Carmo-Fonseca, 1995; Zatsepina et al., 2003). At the initial stages of mouse embryogenesis, pericentric and centromeric heterochromatin was shown to localize around the NPBs (Probst et al., 2007). All these data allows assuming that the NPB-associated heterochromatin represents not just an area of repressed chromatin at the beginning of mouse development, but could be a structural scaffold to form a definitive $3 \mathrm{D}$ architectonics of the cell nucleus.

\section{References}

Banani S.F., Lee H.O., Hyman A.A., Rosen M.K. Biomolecular condensates: organizers of cellular biochemistry. Nat. Rev. Mol. Cell Biol. 2017;18(5):285-298. DOI 10.1038/nrm.2017.7.

Bogolyubova I.O. Transcriptional activity of nuclei in 2-cell blocked mouse embryos. Tissue Cell. 2011;43(4):262-265. DOI 10.1016/j.tice.2011.03.005.

Bogolyubova I.O. Comparative analysis of the fluorescent labeling pattern of nuclei of early mouse embryos by using antibodies to various actin molecule domains. Cell Tiss. Biol. 2013;7(1):37-42. DOI 10.1134/S1990519X13010033.

Bogolyubova I.O., Bogolyubov D.S. An immunocytochemical study of interchromatin granule clusters in early mouse embryos. Biomed. Res. Int. 2013;2013:931564. DOI 10.1155/2013/ 931564.

Bogolyubova I.O., Bogolyubov D.S. Nuclear distribution of RNA polymerase II and mRNA processing machinery in early mammalian embryos. Biomed. Res. Int. 2014;2014:681596. DOI 10.1155/2014/681596.

Bogolyubova I.O., Bogolyubov D.S. Combined detection of newly synthesized RNA and nuclear proteins at the ultrastructural level: a modification of the protocol for immunoelectron microscopy. Cell Tiss. Biol. 2018;12(6):517-522. DOI 10.1134/S1990519X18060020.

Bogolyubova N.A., Bogolyubova I.O. Actin localization in nuclei of two-cell mouse embryos. Cell Tiss. Biol. 2009;3(5):417-422. DOI 10.1134/S1990519X09050034.

Burton A., Torres-Padilla M.E. Epigenetic reprogramming and development: a unique heterochromatin organization in the preimplantation mouse embryo. Brief. Funct. Genomics. 2010; 9(5-6):444-454. DOI 10.1093/bfgp/elq027.

Cho E.J., Kim J.S. Crowding effects on the formation and maintenance of nuclear bodies: insights from molecular-dynamics simulations of simple spherical model particles. Biophys. J. 2012;103(3):424-433. DOI 10.1016/j.bpj.2012.07.007.

Courchaine E.M., Lu A., Neugebauer K.M. Droplet organelles? EMBO J. 2016;35(15):16031612. DOI 10.15252/embj.201593517.

Fadloun A., Le Gras S., Jost B., Ziegler-Birling C., Takahashi H., Gorab E., Carninci P., TorresPadilla M.E. Chromatin signatures and retrotransposon profiling in mouse embryos reveal regulation of LINE-1 by RNA. Nat. Struct. Mol. Biol. 2013;20(3):332-338. DOI 10.1038/ nsmb.2495.

Ferreira J., Carmo-Fonseca M. The biogenesis of the coiled body during early mouse development. Development. 1995;121(2):601-612.

Geuskens M., Alexandre H. Ultrastructural and autoradiographic studies of nucleolar development and rDNA transcription in preimplantation mouse embryos. Cell Differ. 1984;14(2): 125-134. 
Gomes E., Shorter J. The molecular language of membraneless organelles. J. Biol. Chem. 2018. DOI 10.1074/jbc.TM118.001192.

Hamdane N., Tremblay M.G., Dillinger S., Stefanovsky V.Y., Németh A., Moss T. Disruption of the UBF gene induces aberrant somatic nucleolar bodies and disrupts embryo nucleolar precursor bodies. Gene. 2017;612:5-11. DOI 10.1016/j.gene.2016.09.013.

Kopecný V., Flechon J.-E., Camous S., Fulka J.Jr. Nucleologenesis and the onset of transcription in the eight-cell bovine embryo: fine structural autoradiographic study. Mol. Reprod. Dev. 1989;1(2):79-90. DOI $10.1002 / \mathrm{mrd} .1080010202$.

Lanctôt C., Cheutin T., Cremer M., Cavalli G., Cremer T. Dynamic genome architecture in the nuclear space: regulation of gene expression in three dimensions. Nat. Rev. Genet. 2007;8(2):104-115. DOI $10.1038 / \mathrm{nrg} 2041$

Li E. Chromatin modification and epigenetic reprogramming in mammalian development. Nat. Rev. Genet. 2002;3(9):662-673. DOI $10.1038 / \operatorname{nrg} 887$.

Martin C., Beaujean N., Brochard V., Audouard C., Zink D., Debey P. Genome restructuring in mouse embryos during reprogramming and early development. Dev. Biol. 2006;292(2):317-332. DOI 10.1016/j. ydbio.2006.01.009.

Mason K., Liu Z., Aguirre-Lavin T., Beaujean N. Chromatin and epigenetic modifications during early mammalian development. Anim. Reprod. Sci. 2012;134(1-2):45-55. DOI 10.1016/j.anireprosci.2012. 08.010 .

Meglicki M., Teperek-Tkacz M., Borsuk E. Appearance and heterochromatin localization of HP1 $\alpha$ in early mouse embryos depends on cytoplasmic clock and H3S10 phosphorylation. Cell Cycle. 2012; 11(11):2189-2205. DOI 10.4161/cc.20705.

Probst A.V., Santos F., Reik W., Almouzni G., Dean W. Structural differences in centromeric heterochromatin are spatially reconciled on fertilization in the mouse zygote. Chromosoma. 2007;116(4):403415. DOI 10.1007/s00412-007-0106-8.

Rajendra T.K., Praveen K., Matera A.G. Genetic analysis of nuclear bodies: from nondeterministic chaos to deterministic order. Cold Spring Harb. Symp. Quant. Biol. 2010;75:365-374. DOI 10.1101/ sqb.2010.75.043.

Richter K., Nessling M., Lichter P. Macromolecular crowding and its potential impact on nuclear function. Biochim. Biophys. Acta. 2008; 1783(11):2100-2107. DOI 10.1016/j.bbamcr.2008.07.017.
Romanova L., Korobova F., Noniashvilli E., Dyban A., Zatsepina O. High resolution mapping of ribosomal DNA in early mouse embryos by fluorescence in situ hybridization. Biol. Reprod. 2006;74(5):807815. DOI 10.1095/biolreprod.105.047340.

Sailau Z.K., Bogolyubov D.S., Bogolyubova I.O. Nuclear distribution of the chromatin-remodeling protein ATRX in mouse early embryogenesis. Acta Histochem. 2017;119(1):18-25. DOI 10.1016/j.acthis. 2016.11.001.

Santenard A., Ziegler-Birling C., Koch M., Tora L., Bannister A.J., Torres-Padilla M.E. Heterochromatin formation in the mouse embryo requires critical residues of the histone variant H3.3. Nat. Cell Biol. 2010;12(9):853-862. DOI 10.1038/ncb2089.

Sawyer I.A., Bartek J., Dundr M. Phase separated microenvironments inside the cell nucleus are linked to disease and regulate epigenetic state, transcription and RNA processing. Semin. Cell Dev. Biol. 2018a. DOI 10.1016/j.semcdb.2018.07.001.

Sawyer I.A., Sturgill D., Dundr M. Membraneless nuclear organelles and the search for phases within phases. Wiley Interdiscip. Rev. RNA. 2018b;e1514. DOI 10.1002/wrna.1514.

Staněk D., Fox A.H. Nuclear bodies: new insights into structure and function. Curr. Opin. Cell Biol. 2017;46:94-101. DOI 10.1016/j.ceb. 2017.05.001.

Tesařík J., Kopecný V., Plachot M., Mandelbaum J. Activation of nucleolar and extranucleolar RNA synthesis and changes in the ribosomal content of human embryos developing in vitro. J. Reprod. Fertil. 1986a;78(2):463-470.

Tesařík J., Kopecný V., Plachot M., Mandelbaum J., Dalage C., Flechon J.-E. Nucleologenesis in the human embryo developing in vitro: ultrastructural and autoradiographic analysis. Dev. Biol. 1986b;115(1):193-203.

Wang C., Liu X., Gao Y., Yang L., Li C., Liu W., Chen C., Kou X., Zhao Y., Chen J., Wang Y., Le R., Wang H., Duan T., Zhang Y., Gao S. Reprogramming of $\mathrm{H} 3 \mathrm{~K} 9 \mathrm{me} 3$-dependent heterochromatin during mammalian embryo development. Nat. Cell Biol. 2018;20(5):620631. DOI 10.1038/s41556-018-0093-4.

Zatsepina O., Baly C., Chebrou M., Debey P. The step-wise assembly of a functional nucleolus in preimplantation mouse embryos involves the Cajal (coiled) body. Dev. Biol. 2003;253(1):66-83.

Zhu L., Brangwynne C.P. Nuclear bodies: the emerging biophysics of nucleoplasmic phases. Curr. Opin. Cell Biol. 2015;34:23-30. DOI 10.1016/j.ceb.2015.04.003.

Acknowledgements. The work is supported by the granting program of the Presidium of RAS "Molecular and Cell Biology".

Conflict of interest. The authors declare no conflict of interest.

Received November 22, 2018. Revised January 18, 2019. Accepted January 24, 2019. 